\title{
Peran Gereja dalam Transformasi Pelayanan Diakonia
}

\author{
Nimrot Doke Para, Ezra Tari, Welfrid F. Ruku \\ Institut Agama Kristen Negeri Kupang \\ Email: nimrotdokepara290894@gmail.com, tariezra@gmail.com
}

\begin{abstract}
This paper describes the ministry of the church deacon. They are departing from the writer's anxiety about poverty in Indonesia, especially in East Nusa Tenggara. The author focuses on the ministry area of the Congregation Ora Et Labora Oesapa congregation. The approach used by the writer is descriptive qualitative. Based on the research, the authors found; first, the diaconia still focuses on charity and has yet to develop transformational optimally. Second, the deaconess is not yet effective because it has not touched the congregation's needs contextually. Third, the deaconess has not yet found the right way to overcome poverty
\end{abstract}

Key words: Diaconia, Church, Transformation, Poverty

\begin{abstract}
Abstrak
Tulisan ini mengungkapkan pelayanan diakonia gereja. Berangkat dari kegelisahan penulis mengenai kemiskinan di Indonesia, terutama di Nusa Tenggara Timur. Penulis memokuskan di wilayah pelayanan jemaat Ora Et Labora Oesapa. Pendekatan yang dipakai penulis ada kualitatif deskriptif. Berdasarkan penelitian, penulis menemukan, Pertama, diakonia masih berfokus pada karitatif belum mengembangkan transformatis secara maksimal. Kedua, diakonia belum efektif karena belum menyentuh kebutuhan jemaat secara kontekstual. Ketiga, pelayan diakonia belum menemukan dengan baik cara mengatasi kemiskinan
\end{abstract}

Kata kunci: diakonia, Gereja, Transformasi, Kemiskinan

\section{Pendahuluan}

Keadaan miskin adalah persoalan sederhana yang ditemui oleh semua negara, baik negara kaya maupun negara miskin. Kemiskinan disebabkan oleh berbagai hal dalam kehidupan. Kemiskinan dapat menjadi memunculkan berbagai persoalan yakni; kelaparan dan gizi buruk. Selaras dengan pendapat Stott, karakteristik kaum miskin adalah sebagai yakni: pertama, tidak mempunyai penghasilan sendiri seperti tanah, modal atau ketrampilan. Kedua, tidak memiliki aset produksi dengan kekuatan sendiri. Ketiga, tingkat pendidikan yang rendah. Keempat, tinggal di pedesaan dan tidak mempunyai hak kepemilikan tanah. ${ }^{1}$

Bantuan datang belum dapat dipastikan sehingga masyarakat berharap ada dukungan dari luar (bersifat karitatif). Pemberdayaan bersifat karitatif dianggap tidak berhasil sebab masyarakat tidak dapat mengembangkan potensinya. Pemberian bantuan menyebabkan sikap pasif. Kesenjangan antara miskin dan kaya semakin lebar sehingga melalui pelayanan

\footnotetext{
${ }^{1}$ Krido Siswanto, "Tinjauan Teoritis Dan Teologis Terhadap Diakonia Transformatif," Jurnal Simpson, accessed July 31, 2020, http://journal.sttsimpson.ac.id/index.php/Js/article/viewFile/8/7.
} 
diakonia, kesenjangan dalam masyarakat dapat diatasi. ${ }^{2}$ Kemiskinan merupakan situasi yang serba terbatas bukan atas kehendak orang yang bersangkutan. Orang dikatakan miskin bila tingkat pendidikan rendah, produktivitas kerja, pendapatan serta kesehatan. Kemiskinan dapat diakibatkan karena terbatasnya sumber daya manusia, baik lewat jalur pendidikan formal maupun nonformal. Berdasarkan penyebabnya, maka kondisi miskin itu dapat dikelompokkan yaitu pertama struktural, kultural dan rasional. ${ }^{3}$ Lebih lanjut karakteristik penduduk miskin yakni: pertama, tidak mempunyai produksi mandiri. Kedua, pendidikan pada umumnya rendah. Ketiga, tidak mempunyai fasilitas. ${ }^{4}$ Singgih mengemukakan bahwa gereja digambarkan dengan segitiga sama sisi, pada sisi pertama, koinonia (institusional), marturia (ritual) dan diakonia (etikal). ${ }^{5}$ Akses pendidikan yang rendah merupakan persoalan mendasar di negara berkembang. Kemiskinan dan pendidikan yang rendah memberi kontri-busi penting dalam penurunan kualitas hidup dengan signifikan. ${ }^{6}$ Praktik yang menindas struktural membuat petani di wilayah Paroki Mara Satu menjadi miskin, karena pertama, petani tidak pernah mendapatkan bantuan sarana penghasilan dan tempat latihan ketrampilan cara bertani dari pemerintah daerah dan desa. Kedua, para petani tidak dibantu pemerintah untuk dapat memasarkan hasil pertaniannya ke kota Tanjung Selor. Ketiga, petani digunakan sebagai sasaran program bantuan langsung. Keempat, petani dijadikan lumbung perolehan suara oleh calon bupati dan wakil bupati. ${ }^{7}$

Gereja Masehi Injili di Timor (GMIT) memiliki 5 (lima) tugas dan panggilan yang bertujuan untuk mewujudkan apa yang telah diajarkan oleh Tuhan Yesus melalui perkataan dan perbuatan-Nya. Tugas Gereja biasa disebut dengan Panca Pelayanan yakni, Koinonia, Marturia, Diakonia, Liturgia dan Oikonomia. Salah satu tugas Gereja yang akan dibahas dalam penelitian ini yaitu Diakonia. Gereja Masehi Injili di Timor Jemaat Ora Et Labora Oesapa, merupakan Gereja yang cukup besar. Gereja dibangun 19 tahun silam. Dikatakan Gereja besar karena memiliki jumlah jemaat kurang lebih 5.000 jiwa yang tersebar di seputaran Kota Kupang. Sesuai dengan pengertian dan tugas Gereja di atas, GMIT Ora Et Labora Oesapa memiliki panca pelayanan dan panca pelayan tersebut berjalan dengan lancar baik di

${ }^{2}$ Jozef M. N. Hehanussa, "Pelayanan Diakonia Yang Transformatif: Tuntuttan Atau Tantangan," Gema 36, no. 1 (April 2012): 127-138, accessed July 31, 2020, https://journal-

theo.ukdw.ac.id/index.php/gema/article/download/139/130/.

${ }^{3}$ Mariani Febriana, "Pietas Dan Caritas: Pelayanan DIakonia Sebagai Suatu Implementasi Kepedulian Sosial Gereja Untuk Menolong Meretas Angka Kemiskinan Di Indonesia," Jurnal Theologi Aletheia 16, no. 7 (September 2014), accessed August 3, 2020, http://sttaletheia.ac.id.

${ }^{4}$ Fibry Jati Nugroho, "Gereja Dan Kemiskinan: Diskursus Peran Gereja Di Tengah Kemiskinan," Evangelikal: Jurnal Teologi Injili dan Pembinaan Warga Jemaat 3, no. 1 (January 2019): 100-112, accessed August 3, 2020, https://journal.sttsimpson.ac.id/index.php/EJTI.

${ }^{5}$ Agustina Rombe, Pengaruh Pelayanan Diakonia Terhadap Pertumbuhan Gereja Toraja Jemaat Sudiang Makassar (Makassar, 2018), accessed July 31, 2020, https://repository.sttjaffray.ac.id/media/269007pengaruh-pelayanan-diakonia-terhadap-per-24a464cf.pdf.

${ }^{6}$ Grace Sumbung et al., "Peran Gereja Dalam Peningkatan Ekonomi Masyarakat Di Tomohon Sulawesi Utara," Wacana 15, no. 4 (2012), accessed August 4, 2020, https://media.neliti.com/media/publications/40063ID-peran-gereja-dalam-peningkatan-ekonomi-masyarakat-di-tomohon-sulawesi-utara.pdf.

${ }^{7}$ Bobby Steven Timmerman, "Menghadirkan Yesus Kristus Yang Membebaskan 'Para Petani Miskin Yang Tersalib’ Di Paroki Mara Satu: Sebuah Sintesa Kristologi Kontekstual,’ Jurnal Orientasi Baru 23, no. 1 (May 21, 2018), accessed August 4, 2020, https://e-journal.usd.ac.id/index.php/job/article/view/1136. 
bidang kategorial maupun fungsional. Bidang pelayanan diakonia secara khusus diakonia transformatif menjadi menarik untuk diteliti pada diakonia transformatif bagi jemaat kurang mampu di Jemaat GMIT Ora Et Labora Oesapa. Berdasarkan pengamatan penulis dalam kegiatan pra penelitian, latar belakang pekerjaan Jemaat GMIT Ora Et Labora Oesapa 20\% Pegawai, Swasta 25\%, 50\% Buruh/tukang batu, tukang kayu dan 5\% lain-lain. Apabila dilihat berdasarkan latar belakang pekerjaan jemaat maka banyak keluarga yang hidup dalam kurangan. ${ }^{8}$

Pandangan dahulu bahwa profesi sebagai tukang batu, tukang kayu, buruh dan lainlain menjanjikan penghasilan yang cukup untuk hidup dalam berkeluarga justru terbalik di zaman ini, yang mana meningkatnya pencari kerja dan minimnya lapangan kerja serta banyak hal yang dulunya menjadi pekerjaan buruh atau tukang kini tidak lagi dipakai oleh karena tersedianya fasilitas elektronik yang dapat membantu para konsumen, sehingga secara tidak langsung membuat mereka kehilangan pekerjaan. Hal inilah yang perlu diperhatikan oleh Gereja. Dengan pendapatan keuangan Gereja yang besar, penulis berharap Jemaat GMIT Ora Et Labora Oesapa dapat meningkatkan taraf hidup jemaat melalui diakonia transformatif dengan mengambangkan keterampilan yang dimiliki oleh jemaat.

\section{Metode}

Pemeriksaan dengan teliti proses penulisan karya tulis ini menggunakan teknik berdasarkan mutu. Penelitian berusaha menemukan latar natural dari sebuah tempat untuk mengerti kenyataan yang dialami secara menyelururh, dengan membentangkan data dalam bentuk narasi memanfaatkan berbagai cara yang ada. ${ }^{9}$ Peneliti menggunakan bahan kajian pustaka kemudian penulis sajikan secara deskriptif tematis. ${ }^{10}$ Keterangan yang benar dan nyata dianalisis ketika dikumpulkan. Sehingga keterangan itu direduksi, atau dipilah dalam satuan konsep, kategori, dan tema tertentu. ${ }^{11}$ Jika melihat pada tujuan yang hendak dicapai, dalam penelitian ini adalah untuk memahami fenomena empiris, khususnya mencari gambaran mengenai fakta tersebut tanpa memerincinya dalam hubungan antar variabel yang saling terkait. ${ }^{12}$

\footnotetext{
${ }^{8}$ Papan Informasi Statistik Jemaat Ora Et Labora Oesapa.

${ }^{9}$ Lexy J. Moleong, Metode Penelitian Kualitatif (Bandung: Remaja Rosdakarya, 2006), 6.

${ }^{10}$ Selvester Melanton Tacoy, "Pelayanan Dalam Konteks Masyarakat Perkotaan," Jurnal Teologi Kontekstual Indonesia 1, no. 1 (June 29, 2020): 36, accessed August 4, 2020, https://journal.sttsimpson.ac.id/index.php/JTKI/article/view/300.

${ }^{11}$ Ahmad Rijali, “Analisis Data Kualitatif," Jurnal Alhadharah 17, no. 33 (2018), accessed August 4, 2020, https://jurnal.uin-antasari.ac.id/index.php.

${ }^{12}$ Sonny Eli Zaluchu, "Strategi Penelitian Kualitatif Dan Kuantitatif Di Dalam Penelitian Agama," Evangelikal: Jurnal Teologi Injili dan Pembinaan Warga Jemaat 4, no. 1 (January 31, 2020): 28, accessed June 22, 2020, https://journal.sttsimpson.ac.id/index.php/EJTI/article/view/167.
} 


\section{Hasil dan Pembahasan}

\section{Hasil}

Berdasarkan hasil penelitian mengenai diakonia yang penulis peroleh dari responden ialah mereka pernah mendapatkan pelayanan diakonia dari Gereja yang diberikan Beras $5 \mathrm{~kg}$, Bimoli 2 Ltr, Sabun Cuci Daia 1 Kg, Sabun Mandi Lifebouy 1/2 Lusin, Gula 1 Kg dan Teh Celup 1 Kotak. Dengan kata lain para jemaat Ora Et Labora Oesapa pernah menerima diakonia yang sifatnya habis pakai berupa Sembilan bahan pokok.

Berdasarkan hasil yang penulis pelayanan diakonia karitatif yang dilakukan gereja ialah mereka menerima pelayanan diakonia dari Gereja sebanyak empat (4) kali dalam setahun. Dengan kata lain pelayanan diakonia yang diberikan bersifat habis pakai, yang memang secara realita hanya akan dapat membantu jemaat dalam jangka waktu yang singkat. Jemaat penerima diakonia ini akan terus mendapatkan pelayanan diakonia dari Gereja secara periodik (empat kali dalam setahun) tergantung hasil pendataan jemaat. para penerima mengatakan bahwa pelayanan diakonia ini sudah baik, karena mereka selalu mendapat pelayanan diakonia dari Gereja. Majelis yang mengatur diakonia juga selalu mengajak mereka berdoa mengucap syukur bersama-sama di Gereja sebelum mereka menerima diakonia. Mereka juga memberikan tanggapan bahwa kalau bisa seperti di Gereja lain memberikan pelatihan dan kursus serta sedikit modal untuk jemaat bisa berusaha lewat bantuan tersebut.

Gereja Ora Et Labora Oesapa memiliki pelayanan diakonia yang cukup bagi jemaatnya secara Karitatif namun, ada beberapa hal yang belum maksimal di lakukan oleh Gereja Ora Et Labora Oesapa yakni, Gereja belum maksimal memberikan edukasi kepada jemaatnya tentang diakonia itu sendiri, sehingga jemaat khususnya para penerima diakonia belum memahami secara baik apa itu diakonia \& jenis-jenis diakonia dll. Berikutnya, Gereja Ora Et Labora Oesapa belum secara maksimal memberikan jenis pelayanan diakonia lainnya seperti diakonia reformatif dan diakonia transformatif.

Hasil yang penulis peroleh mengenai perasaan jemaat mendapatkan pelayanan diakonia dari responden ialah mereka merasa bersyukur, merasa sangat terbantu dan senang. Dengan kata lain, Gereja sebagai saranah kesaksian Tuhan kepada manusia yang ada dalam dunia terus berperan untuk membawa shalom Allah melalui panca pelayanannya, secara khusus di bidang diakonia. Pelayanan yang diberikan dengan menggunakan pendekatan yang yang tepat membuat jemaat merasa tersentuh sehingga pemberian pelayanan diakonia tidak hanya membantu meringankan kebutuhan ekonomi tetapi juga secara psikologi dan spiritual jemaat. Hasil yang penulis peroleh pelayanan diakonia reformatif ditemukan, mereka belum pernah mendapatkan mereka belum mendapatkan pelayanan diakonia yang dapat membantu mereka untuk membuka usaha kecil-kecilan atau pengembangan usaha mereka mungkin itu lebih baik lagi. Penghasilan juga yang tidak tetap. Dengan begitu istri mereka dapat berdaya melalui usaha kecil-kecilan yang datang melalui pelayanan diakonia dari Gereja, demikian jawaban para responden. 
Pelayanan diakonia reformatif belum berperan dan menyentuh jemaat, sehingga jemaat masih terus menerima diakonia karitatif dan berharap Gereja bertransformasi dari diakonia karitatif ke jenis diakonia yang lainnya agar jemaat dapat diberdayakan. Hasil yang penulis pada waktu pembagian diakonia, saat itu juga mereka bersama pelayan (majelis) langsung bersama-sama melakukan ibadah sebagai tanda syukur mereka atas diakonia yang sudah mereka terima. Setelah itu mereka membawa pulang diakonia yang diberikan dan kami berdo,a khusus bersama keluarga dirumah kami lagi baru kami gunakan sesuai kebutuhan kami. Lebih dari itu mereka merasa Gereja sangat dekat dengan mereka sehingga tiba waktu kegiatan di Gereja mereka merasa harus terlibat dan ketika mereka tidak terlibat maka ada yang kurang, demikian jawaban para responden.

Berdasarkan hasil penelitian mengenai pelayanan gereja dalam bentuk bantuan hokum ialah mereka belum pernah dibantu oleh pihak Gereja ketika kami mengalami ketidak adilan terkait pelanggaran hak asasi manusia dalam taraf yang tinggi (misalkan sampai ke pihak kepolisian atau pengadilan dll.), karna bagi mereka itu bukan tanggung jawab Gereja, tapi tetangga kami pernah didatangi oleh majelis untuk mendamaikan jemaat yang mengalami kekerasan dalam rumah tangga, istrinya melapor ke majelis yang kebetulan rumah berdekatan. Dengan kata lain pertanyaan wawancara yang mengacu pada diakonia transformatif belum diatur dan diterapkan. Hasil yang penulis peroleh secara langsung bahwa mereka tahu tujuan diakonia adalah untuk membantu keluarga penerima diakonia yang kurang mampu, tapi saat dalam pemberian diakonia mereka tidak pernah diberitahu tentang tujuan lain yang mungkin ada dari pihak Gereja. Dengan kata lain sosialisasi dan edukasi tentang diakonia belum dilakukan secara maksimal kepada jemaat sehingga jemaat atau para penerima diakonia belum mengetahui secara spesifik tentang tujuan diakonia.

Berdasarkan hasil yang penulis peroleh berdasarkan program pelayanan tahun terakhir (2019), total anggaran yang disiapkan dalam merealisasikan Panca Pelayananan sebesar Rp.192.500.000. Dan secara khusus alokasi anggaran yang disiapkan untuk bidang pelayanan pos pelayanan diakonia yang ada dalam anggaran diperuntukkan untuk: 1) Pelayanan kasih untuk janda dan keluarga kurang mampu. 2) Bantuan kedukaan bagi jemaat yang berduka. 3) Bantuan bagi jemaat yang sakit. diakonia sebesar Rp. 62.500.000. Hasil yang penulis peroleh dari para responden ialah Perlu dijelaskan bahwa pelayanan diakonia yang dilaksanakan selalu dipantau mulai dari proses hingga sampai pada jemaat menerima diakonia, selanjutnya pemanfaatan dilakukan secara internal oleh pihak penerima/keluarga.

\section{Pembahasan}

Pelayanan Diakonia Karitatif

Berdasarkan hasil penelitian, pada umumnya menyatakan bahwa pelaksanaan pelayanan Diakonia (Karitatif) yang dialaksanakan oleh presbiter, dalam hal ini Unit Pembantu Pelayanan (UPP) Diakonia Jemaat GMIT Ora Et Labora Oesapa dilakukan secara rutin 
sebagai kewajiban dalam panca pelayanan. Adapun bentuk diakonia yang mereka dapat berupa: Beras 5 kg, Minyak Goreng Bimoli 2 Ltr, Sabun Cuci Daia 1 Kg, Sabun Mandi Lifebouy $1 \frac{2}{2}$ Lusin, Gula $1 \mathrm{Kg}$ dan Teh Celup 1 Kotak.

Dalam hasil penelitian, juga didapati bahwa Jemaat (GMIT) Ora Et Labora Oesapa yang ada di bawah payung hukum dan organisasi Gereja Masehi Injili di Timor (GMIT), turut melaksanakan kewajibannya dalam pelayanan Diakonia (Karitatif) yang di laksanakan selama empat kali dalam setahun atau setara dengan tiga bulan sekali. Sesuai dengan uraian tentang diakonia di atas, maka Gereja Masehi Injili di Timor (GMIT) juga merangkumnya dalam tata dasar GMIT, BAB IV Paragraf 3, Pasal 16 tentang pelayanan kasih, tertulis: pertama, penatalayanan dilakukan dengan meneladani Yesus. Kedua, kasih harus dilaksanakan dengan berpihak pada yang lemah dan terpinggirkan. ${ }^{13}$

Widiatmadja mengemukakan bahwa diakonia karitatif diterima dengan mudah karena: Pertama, memberikan faedah langsung dan dapat dilihat. Kedua, tidak ada resiko, sebab didukung oleh penguasa. Ketiga, memberikan penam-pilan yang baik terhadap si pemberi. Keempat, memusatkan perhatian pada hubungan pribadi. Kelima, menciptakan hubungan subjek-objek (ketergantungan) dan status quo. ${ }^{14}$ Ia melihat bahwa diakonia sering diwujudkan dalam bentuk pemberian makanan, pakaian untuk orang miskin, menghibur orang sakit dan pembuatan amal kebajikan lainnya. Sehingga diakonia dipahami juga sebagai "pelayanan kasih" yaitu dengan memperhatikan dan menyediakan kebutuhan-kebutuhan fisik orang miskin, yang sakit, yang lemah dan yang hidup dalam rupa-rupa kesusahan. Tindakan Allah dalam memelihara orang-orang yang tidak berdaya tersebut ditugasi Allah kepada umat-Nya Israel (Ul. 15:7-18). Bangsa Israel bertugas dan bertanggungjawab memelihara dan melayani orang asing, anak yatim, janda-janda dan orang miskin dengan jalan memberikan sebagian hasil panennya bagi mereka untuk kelangsungan hidupnya. Seperti yang dipahami dari pemikiran John Stott bahwa setiap orang dipanggil keluar dari dunia untuk menjadi milik Allah dan diutus kembali ke dunia untuk menjadi saksi dan melayani. ${ }^{15}$ Paulus berkata saling tolong-menolonglah dalam memikul beban (Gal. 6:2). Biasanya orang yang mau membantu adalah orang yang mempunyai kepekaan. Kasih yang ada pada diri seseorang adalah dipakai untuk saling menolong (Yoh. 13:34-35). Motivasi perbuatan karitatif didorong oleh rasa kemanusiaan yang alamiah. Sehingga umat Tuhan terpanggil untuk membebaskan umat dari penderitaan yang dihadapi. ${ }^{16}$

Berdasarkan pemaparan tersebut maka penulis berpendapat bahwa pelaksanaan pelayanan Diakonia (Karitatif) yang dialaksanakan oleh presbiter, dalam hal ini Unit Pembantu

\footnotetext{
${ }^{13}$ Sinode Gereja Masehi Injili di Timor, Ketetapan Sinode Gereja Masehi Injili Di Timor Tentang Tata Dasar GMIT (Kupang, 2015), 58-59.

${ }^{14}$ Yosef Purnama Widyatmadja, Diakonia Sebagai Misi Gereja: Praksis Dan Refleksi Diakonia Transformatif (Yogyakarta: Kanisius, 2009), 109.

${ }^{15}$ John R. W. Stott, The Living Church: Menggapai Pesan Kitab Suci Yang Versifat Tetap Dalam Budaya Berubah (Jakarta: BPK Gunung Mulia, 2010), 2.

${ }^{16}$ George Likumahwa, John Titaley, and Steve Gaspersz, "Keluar Dari Kemiskinan: Studi Pembangunan Dan Pemberdayaan Jemaat Di Dusun Siahari, Kecamatan Seram Utara Titmur," ARUMBAE: Jurnal Ilmiah Teologi dan Studi Agama 2 (2020): 91-109.
} 
Pelayanan (UPP) Diakonia Jemaat GMIT Ora Et Labora Oesapa sampai dengan saat ini berjalan dengan baik, oleh karena masih berjalan sesuai dengan jadwal triwulan yang telah ditetapkan.

\section{Pelayanan Diakonia Reformatif}

Berdasarkan hasil penelitian, pelaksanaan pelayanan diakonia reformatif yang dalam prakteknya berupa peminjaman modal usaha atau kursus keterampilan dan pelatihan lainnya, yang sifatnya pengembangan atau pemberdayaan jemaat belum pernah mereka dapatkan. Apabila adapun mereka tidak mendapat informasi terkait pelayanan tersebut. Dengan kata lain pertanyaan yang mengacu pada pelayan diakonia refromatif. Bertujuan untuk menghidupkan dan mengembangkan atau memberdayakan serta meningkatkan keterampilan jemaat. Namun berdasarkan jawaban para responden, mereka belum pernah mendapatkan jenis pelayanan seperti dalam uraian di atas.

Diakonia reformatif menekankan pembangunan. Pendekatan yang dilakukan adalah pengembangan komunitas seperti pembangunan pusat kesehatan, penyuluhan, bimas, usaha bersama simpan pinjam, dan lain-lain. Analogi model ini adalah bila ada orang lapar berikan makanan (roti, ikan) dan pacul atau kail supaya ia tidak sekedar meminta tetapi juga mengusahakan sendiri. Pada jenis ini, diakonia tidak lagi sekedar memberikan bantuan pangan dan pakaian, tetapi mulai memberikan perhatian pada penyelenggaraan kursus keterampilan, pemberian atau pinjaman modal pada kelompok jemaat.

Pentingnya diakonia bagi Gereja dapat juga dipahami dari pemikiran Sikkel yang mengemukakan bahwa Gereja bisa hidup tanpa gedung, tetapi Gereja tidak bisa hidup tanpa diakonia. ${ }^{17}$ Mengacu pada pemahaman ini jelas menggambarkan betapa pentingnya diakonia untuk kehidupan Gereja. Bahkan dijelaskan juga gerakan Yesus tidak dapat dipisahkan dengan gerakan solidaritas bagi masyarakat miskin. Sifat gerakan solidaritas tersebut dipraktikkan melalui diakonia Gereja. Disamping itu juga, pentingnya diakonia tidak dapat dilepaskan dengan tujuan diakonia adalah untuk mewujudkan manusia dan dunia baru. Diakonia tidak dimaksudkan sekedar untuk menciptakan hubungan antara pemberi dan penerima.

Ketika membicarakan jemaat miskin, maka kemudian akan muncul dalam benak tentang pergumulan Gereja akan masalah-masalah seperti kemiskinan, ketidakadilan, penderitaan, ketimpangan, ketidakberdayaan, terpinggirkan, lemah, dan konotasi yang bersifat negatif lainnya. Padahal, mereka adalah makhluk ciptaan Tuhan yang perlu mendapatkan diakonia yang tidak hanya terbatas dalam arti sebagai amal, tetapi pemberian diakonia itu pada hakikatnya merupakan hak setiap orang, termasuk di dalamnya adalah orang miskin dan tertindas. Yesus sebagai teladan yang menampakkan diri sebagai Putra Allah memilih lahir dalam pangkuan orang-orang lemah dan miskin. Diakonia yang dilakukan gereja bukan merupakan kegiatan berdimensi santunan sosial. Melainkan sebagai tugas dalam menanggapi perbin-

${ }^{17}$ Yosef Purnama Widyatmadja, Yesus Dan Wong Cilik: Praksis Diakonia Transformatif Dan Teologi Rakyat Di Indonesia (Jakarta: BPK Gunung Mulia, 2010), 1. 
cangan dalam masyarakat mengenai masalah kekurangan. ${ }^{18}$ Berdasarkan uraian di atas maka penulis mengemukkan bahwa setiap orang Kristen harus terlibat dalam menolong orang yang kesusahan atau yang sedang membutuhkan bantuan. Seperti Yesus yang memperhatikan orang yang berkekurangan begitu juga manusia harus memperhatikan sesama. Cara dan bentuk pelayanan dan bahan-bahan yang digunakan berbeda-beda, tetapi tidak boleh ada seorangpun diantara mereka (butuh pertolongan) yang dilampaui atau dilupakan. Tujuan pelayanan supaya anggota jemaat menjadi orang-orang percaya yang dewasa sehingga dapat menunaikan tugas yang dipercayakan dengan baik.

\section{Pelayanan Diakonia Transformatif}

Berdasarkan hasil penelitian yang penulis peroleh dari para responden ialah mereka belum pernah dibantu oleh pihak Gereja ketika mereka mengalami ketidak adilan terkait pelanggaran hak asasi manusia dalam taraf tertentu (misalkan sampai ke pihak kepolisian atau pengadilan dll), karna sepengetahuan mereka itu bukan tanggung jawab Gereja, namun pernah juga presbiter datang untuk menangani peristiwa dalam suatu moment pertengkaran/kekerasan dalam rumah tangga terjadi pada salah satu jemaat. Dengan kata lain pertanyaan wawancara yang mengacu pada diakonia transformatif tersebut belum diatur dan dalam jemaat. Sedangkan menurut Artanto, diakonia transformatif adalah pengembangan misi pembebasan yang dilakukan gereja menghadapi kenyataan sosial. Karena itu, gereja melaksanakan diakonia transformatif berguna untuk menyatakan perbuatan adil terhadap orang-orang miskin dan memperjungkan hak-hak hidupnya. ${ }^{19}$ Salah satu kategori yang ditekankan dalam diakonia transformatif adalah persatuan dalam aturan kehidupan manusia yang baru. Persatuan mengandung makna persekutuan dalam Kristus dan sesama yang mencakup orang yang memerlukan pertolongan. Sementara itu dasar-dasar Alkitabiah tugas diakonia transformatif terletak pada berita tentang Kerajaan Allah yang menjadi pengajaran Yesus. Tugas Gereja adalah menghadirkan tanda-tanda Kerajaan Allah (Luk. 4:18-19). Keyakinan akan kedatangan Kerajaan Allah menggambarkan suatu masyarakat yang sesuai dengan kehendak Allah. Masyarakat diwarnai oleh kasih, pengampunan, pelayanan, keseimbangan, kekudusan, kedamaian dan sukacita.

Adapun ciri-ciri utama Kerajaan Allah sebagai berikut: Pertama Kasih, kasih harus menjadi dasar kehidupan orang percaya, kehidupan dan akivitasnya dimotivasi oleh kasih. Kasih dari Allah (Agape) tidak membeda-bedakan, tidak memandang muka. Kasih bukan hanya sikap batin tetapi perlu dinampakkan dalam perbuatan yang konkrit. Kasih berarti ada keinginan untuk menolong dengan perbuatan yang nyata. Kedua Keadilan, kewajiban sebagai orang Kristen dan sebagai bagian dalam masyarakat hendaknya menampilkan ciri masyarakat

${ }^{18}$ Erman S. Saragih, "Fungsi Gereja Sebagai Entrepreneurship Sosial Dalam Masyarakat Majemuk," Kurios: Jurnal Teologi dan Pendidikan Agama Kristen 5, no. 1 (April 2019): 12-23, accessed August 10, 2020, http://www.sttpb.ac.id/e-journal/index.php/kurios. 213.

${ }^{19}$ Widi. Artanto, Menjadi Gereja Misioner Dalam Konteks Indonesia (Yogyakarta: Kanisius, 2002), 
yang baik tanpa diskriminasi, dan saling menghargai sebagai sesama ciptaan Tuhan. Konsep keadilan secara ekonomi, pertanggungjawaban dan menggunakan kemampuan kreatif kita sebagai bagian dari ciptaan yang diciptakan menurut rupa dan gambar Allah. Ketiga Damai sejahtera, damai sejahtera atau syalom berarti kedamaian, persatuan, keselamatan, kesejahteraan, kesehatan, keadilan dan persekutuan. Dalam Perjanjian Baru panggilan Kerajaan Allah adalah untuk memberikan kepenuhan dan kelimpahan hidup bagi semua orang

Demikian halnya dengan model diakonia reformatif yang menekankan aspek pembangunan dengan analogi "pemberian pancing dan keahlian memancing" juga kurang bermanfaat jika keahlian dan ketrampilan tersebut tidak dapat digunakan bila peluang dan akses tidak tersedia baginya. Diakonia transformatif yang sifatnya memberdayakan orang yang lemah dan miskin. Diakonia transformatif juga kritis terhadap kebijakan-kebijakan publik yang tidak adil dan tak ragu-ragu melakukan kecaman sosial. ${ }^{20}$ Dalam menghadapi masalah yang multi aspek dan multidimensional masa kini, Gereja harus mampu melakukan revisi, reorientasi serta rekonstruksi ajaran-ajaran, perilaku dan pelayanannya supaya dapat memberikan sumbangan yang bermakna bagi manusia, dunia dan peradabannya, sehingga melaluinya gereja akan mampu menjalankan pelayanan yang transformatif. Dalam hal ini penulis berpendapat bahwa praktik diakonia karitatif penting dalam pelayanan gereja. Namun, praktik diakonia pembangunan dan transformatif tidak kalah penting dalam konteks kepelayanan gereja secara holistik. Pemecahan problem kemiskinan dan ketidak adilan bagi jemaat tampaknya tidak memadai lagi bila hanya dengan praktik diakonia karitatif. Melainkan pelayanan membutuhkan sentuhan baru dalam konteks penatalayanan yakni praktik diakonia reformatif dan transformatif yang dilukisan dengan gambar mata terbuka.

Penerima Pelayanan Diakonia dan Pemanfaatannya.

Berdasarkan hasil penelitian pemanfaatan bantuan diakonia karitatif, langsung digunakan setelah dibagikan oleh para presbiter yang bertugas, oleh karena bantuan diakonia yang didapatkan selama ini bersifat habis pakai dan memiliki batas waktu pemakaian. Namun sayangnya dampak tersebut tidak akan bertahan lama karena pemberian tersebut bersifat habis pakai dan tidak ada pemanfaatan untuk pengembangan bagi penerima diakonia tersebut. Pemberian diakonia telah dilakukan sejak jemaat Ora Et Labora Oesapa berdiri hingga saat ini atau dengan kata lain pelayanan diakonia tersebut telah dilakukan selama bertahun-tahun dengan jenis (Diakonia Karitatif) dan dalam bentuk yang sama (Sembako) kepada jemaat. Namun jemaat yang menerima pelayanan diakonia masih tetap berada dalam realitas kemiskinan (tidak mengalami perubahan hidup).

${ }^{20}$ Boydo Rajiv E. D. Hutagalung, "Diakonia Transformatif Sebagai Pewujudan Diakonia Yang Holistik Dan Relevan Sebuah Tafsiran Atas Kisah Para Rasul 6:1-15? , Wajana Teologi: Jurnal Ilmiah Mahasiswa Teologi Duta Wacana 5, no. 1 (2013), accessed August 11, 2020, http://journaltheo.ukdw.ac.id/index.php/wacana/article/view/152. 


\section{Tujuan Diakonia Bagi Jemaat}

Berdasarkan hasil penelitian, tujuan diakonia adalah memberdayakan jemaat yang kurang mampu dan mengangkat mereka dari keadaan sulit yang dialami. Sementara itu berdasarkan realita dalam hasil penelitian penulis dengan jemaat, ditemukan bahwa dalam menerima pelayanan atau bantuan diakonia dari pihak Gereja, mereka sendiri hanya menerima pelayanan tersebut dengan konsep pengetahuan bahwa diakonia ada oleh karena sudah terprogram dan mau tidak mau harus dijalankan sebagai kewajiban pihak Gereja terhadap jemaat. Diakonia dilihat sebagai sifat setia kawan terhadap orang lain berdasarkan belas kasih. Diakonia bukan lagi hanya berbuat amal yang dilakukan oleh gereja melainkan melakukan perubahan terhadap manusia yang ada dalam sistem dan struktur kehidupan. ${ }^{21}$ Di samping itu, diakonia sangat penting, jika dikaitkan dengan tujuan diakonia. Diakonia tidak dimaksudkan untuk membentuk hubungan antara pemberi dan penerima. Diakonia harus dilaksanakan dalam rangka misi Allah dalam dunia yakni, hadirnya pemerintahan Allah di dunia. Praktik dari diakonia belum nampak memberikan sumbangan terhadap kehidupan jemaat. Karena jemaat yang kurang mampu tidak berkurang dalam jumlah angka. Gereja hanya menyediakan bantuan beras untuk keluarga miskin dan para janda dan duda, mengunjungi jemaat dalam penjara dan berlomba dalam membangun gedung yang megah. Ketidakseimbangan antara jemaat kaya dan miskin merupakan fakta yang nyata dalam kehidupan berjemaat. Nampaknya, pelayanan pelayanan hanya memokuskan perhatian pada bantuan barang habis pakai yang diberikan kepada jemaat belum mampu. Mereka butuh pemberdayaan dalam kerangka misi di dunia. Mereka bukan hanya dilihat sebagai pihak yang perlu menerima diakonia, tetapi perlu dilatih melalui proses penyadaran dan pemberdayaan agar mampu menjadi pemberi diakonia.

Berdasarkan uraian-uraian sebelumnya maka penulis dapat memberi pernyataan bahwa pelayanan diakonia jemaat Ora Et Labora Oesapa belum dapat dikatakan berhasil oleh karena belum mencapai tujuan dan belum mampu memberi perubahan bagi jemaat itu sendiri, dengan kata lain suatu pelayanan diakonia baru dikatakan berhasil apabila pelayanan diakonia tersebut dapat mengentaskan kemiskinan atau mengubah kehidupan penerima diakonia, sebaliknya jika pelayanan diakonia tersebut tidak dapat mengubah kehidupan penerima diakonia maka pelayanan diakonia tersebut sia-sia.

\section{Usaha Kecil Sebagai Strategi Diakonia}

Usaha kecil dan menengah memiliki peran yang penting dalam mengembangkan ekonomi masyarakat. Karena usaha kecil lebih fleksibel dalam pelaksanaannya. Pengembangan usaha kecil dapat memberikan sumbangsih pada pertumbuhan ekonomi jangka panjang. Perkembangan usaha kecil merupakan bagian sederhana dalam penciptaan lapangan

${ }^{21}$ Sudianto Manullang, "Konsep Misi-Diakonia Untuk Konteks Indonesia," Stulos 16, no. 1 (January 2018): 28-46, accessed August 11, 2020, http://www.sttb.ac.id/. 
kerja. Di daerah terpencil, pengembangan usaha kecil menjadi kunci dalam usaha mengentaskan problem kemiskinan dan pembangunan ekonomi daerah yang lebih berimbang.

Salah satu contoh praktik yang dilakukan jemaat GPdI Elshaddai Wamena meliputi; pertama, perdagangan makanan dan minuman yaitu warung kelontong, warung nasi, mie bakso, sayuran, jamu. Kedua, jasa seperti; tambal ban, bengkel motor, tukang las, penjahit. Ketiga, pengrajin yaitu perkayuan. Keempat, pertanian atau peternakan dan perikanan. Kelima, usaha perdagangan seperti kaki lima, serta pedagang di pasar dan lain-lain. Keenam, usaha jasa-jasa seperti perbengkelan, salon kecantikan, ojek dan penjahit. ${ }^{22}$ Karena itu, perlu penyediaan sistem untuk memastikan penatalayanan secara menyeluruh. Pendeta tidak ikut mengambil atau mempengaruhi keputusan yang berkaitan dengan pinjaman modal dalam pengembangan usaha kecil. Serta fokus pada percepatan tabungan untuk membangun permodalan. Usaha menyediakan skema asuransi untuk mengantisipasi keadaan darurat. Berusaha merestrukturisasi program sehingga lembaga memiliki jati diri sebagai komunitas.

Ciri pengembangan usaha kecil yang kristiani yakni, fokus pada pembukaan lapangan pekerjaan dan menciptakan penghasilan dalam skala kecil. Pengembangan usaha kecil menyediakan bagi orang miskin akses kepada modal dan pelatihan untuk memulai dalam pengembangan usaha. Sebuah pandangan holistik yang mendasari program pengembangan usaha kecil kristiani adalah penyatuan identitas sebagai orang yang bertanggung jawab sebagai pengelola sumber materi. Ada perpaduan tanggung jawab pribadi dengan keluar komunitas. Hal ini menggabungkan semuanya dengan mandat untuk membangun taman Tuhan yaitu kelompok masyarakat dan lingkungan. Selain itu untuk mengisi kerinduan spiritual dan material. Program pengembangan usaha kecil memberikan kesempatan kepada orang kurang mampu untuk menunjukkan tanggung jawab ilahi dan menerapkan kewirausahaan secara kreatif dalam melayani orang lain.

\section{Kesimpulan}

Berdasarkan pemaparan di atas, penulis menyinpulkan yakni: pertama, Pelayanan diakonia bagi jemaat kurang mampu di Jemaat GMIT Ora Et Labora Oesapa selama ini berjalan dengan baik pada ranah diakonia karitatif namun belum berjalan dengan maksimal pada ranah diakonia yang lain sehingga jemaat penerima terus menerima pelayanan diakonia namun belum mengalami perubahan hidup, jemaat yang kurang mampu belum mengalami pemberdayaan atau perubahan dari pelayanan diakonia Gereja tersebut. sehingga perlu adanya pelayanan diakonia yang memberdayakan jemaat. Kedua: Pelayanan diakonia karitatif diberikan secara sukarela sebagai amal dan diperuntukkan bagi jemaat berkesusahan yang mengalami musibah atau bencana alam dan lain sebagainya yang sifatnya konsumtif (habis pakai), sehingga secara kontekstualnya jemaat kurang mampu lebih membutuhkan pemberdayaan, sehingga pelayanan diakonia jemaat GMIT Ora Et Labora Oesapa dinilai belum

\footnotetext{
${ }^{22}$ Mika Daddu Ngedi, "Praktik Kewirausahaaan Gereja: Upaya Gereja Pentakosta Dalam Mengentaskan Kemiskinan Di Kota Wamena," Visio Dei: Jurnal Teologi Kristen 1, no. 1 (June 27, 2019): 1937, accessed August 11, 2020, http://www.jurnal.sttstarslub.ac.id/index.php/js/article/view/8.
} 
efektif dalam pelayanan diakonianya, karena belum menjawab kebutuhan jemaat secara kontekstual. Ketiga: Para pelayan jemaat Ora Et Labora Oesapa belum maksimal dalam melihat keadaan dan kebutuhan jemaat Ora Et Labora Oesapa dalam konteks penerapan pelayanan diakonia sehingga perlu melakukan transformasi pelayanan diakonia, yang sebelumnya berfokus pada Diakonia karitatif mesti bertransformasi dan menerapkan pola pelayanan diakonia reformatif dan diakonia transformatif sebagai upaya menolong jemaat dari kemiskinan.

\section{Rujukan}

Artanto, Widi. Menjadi Gereja Misioner Dalam Konteks Indonesia. Yogyakarta: Kanisius, 2002.

Febriana, Mariani. "Pietas Dan Caritas: Pelayanan DIakonia Sebagai Suatu Implementasi Kepedulian Sosial Gereja Untuk Menolong Meretas Angka Kemiskinan Di Indonesia.” Jurnal Theologi Aletheia 16, no. 7 (September 2014). Accessed August 3, 2020. http://sttaletheia.ac.id.

Hehanussa, Jozef M. N. "Pelayanan Diakonia Yang Transformatif: Tuntuttan Atau Tantangan.” Gema 36, no. 1 (April 2012): 127-138. Accessed July 31, 2020. https://journal-theo.ukdw.ac.id/index.php/gema/article/download/139/130/.

Hutagalung, Boydo Rajiv E. D. "Diakonia Transformatif Sebagai Pewujudan Diakonia Yang Holistik Dan Relevan Sebuah Tafsiran Atas Kisah Para Rasul 6:1-15? ." Wajana Teologi: Jurnal Ilmiah Mahasiswa Teologi Duta Wacana 5, no. 1 (2013). Accessed August 11, 2020. http://journal-theo.ukdw.ac.id/index.php/wacana/article/view/152. Likumahwa, George, John Titaley, and Steve Gaspersz. "Keluar Dari Kemiskinan: Studi Pembangunan Dan Pemberdayaan Jemaat Di Dusun Siahari, Kecamatan Seram Utara Titmur." ARUMBAE: Jurnal Ilmiah Teologi dan Studi Agama 2 (2020): 91-109. Manullang, Sudianto. “Konsep Misi-Diakonia Untuk Konteks Indonesia.” Stulos 16, no. 1 (January 2018): 28-46. Accessed August 11, 2020. http://www.sttb.ac.id/.

Moleong, Lexy J. Metode Penelitian Kualitatif. Bandung: Remaja Rosdakarya, 2006.

Ngedi, Mika Daddu. "Praktik Kewirausahaaan Gereja: Upaya Gereja Pentakosta Dalam Mengentaskan Kemiskinan Di Kota Wamena.” Visio Dei: Jurnal Teologi Kristen 1, no. 1 (June 27, 2019): 19-37. Accessed August 11, 2020.

http://www.jurnal.sttstarslub.ac.id/index.php/js/article/view/8.

Nugroho, Fibry Jati. “Gereja Dan Kemiskinan: Diskursus Peran Gereja Di Tengah

Kemiskinan." Evangelikal: Jurnal Teologi Injili dan Pembinaan Warga Jemaat 3, no. 1 (January 2019): 100-112. Accessed August 3, 2020.

https://journal.sttsimpson.ac.id/index.php/EJTI.

Rijali, Ahmad. “Analisis Data Kualitatif.” Jurnal Alhadharah 17, no. 33 (2018). Accessed

August 4, 2020. https://jurnal.uin-antasari.ac.id/index.php.

Rombe, Agustina. Pengaruh Pelayanan Diakonia Terhadap Pertumbuhan Gereja Toraja

Jemaat Sudiang Makassar. Makassar, 2018. Accessed July 31, 2020.

https://repository.sttjaffray.ac.id/media/269007-pengaruh-pelayanan-diakonia-terhadap- 
per-24a464cf.pdf.

Saragih, Erman S. "Fungsi Gereja Sebagai Entrepreneurship Sosial Dalam Masyarakat

Majemuk." Kurios: Jurnal Teologi dan Pendidikan Agama Kristen 5, no. 1 (April

2019): 12-23. Accessed August 10, 2020. http://www.sttpb.ac.id/e-

journal/index.php/kurios.

Sinode Gereja Masehi Injili di Timor. Ketetapan Sinode Gereja Masehi Injili Di Timor

Tentang Tata Dasar GMIT. Kupang, 2015.

Siswanto, Krido. “Tinjauan Teoritis Dan Teologis Terhadap Diakonia Transformatif.” Jurnal

Simpson. Accessed July 31, 2020.

http://journal.sttsimpson.ac.id/index.php/Js/article/viewFile/8/7.

Stott, John R. W. The Living Church: Menggapai Pesan Kitab Suci Yang Versifat Tetap

Dalam Budaya Berubah. Jakarta: BPK Gunung Mulia, 2010.

Sumbung, Grace, Agus Suman, Kliwon Hidayat, and Paulus Kindangen. "Peran Gereja

Dalam Peningkatan Ekonomi Masyarakat Di Tomohon Sulawesi Utara.” Wacana 15,

no. 4 (2012). Accessed August 4, 2020.

https://media.neliti.com/media/publications/40063-ID-peran-gereja-dalam-peningkatan-

ekonomi-masyarakat-di-tomohon-sulawesi-utara.pdf.

Tacoy, Selvester Melanton. "Pelayanan Dalam Konteks Masyarakat Perkotaan.” Jurnal

Teologi Kontekstual Indonesia 1, no. 1 (June 29, 2020): 36. Accessed August 4, 2020.

https://journal.sttsimpson.ac.id/index.php/JTKI/article/view/300.

Timmerman, Bobby Steven. "Menghadirkan Yesus Kristus Yang Membebaskan 'Para Petani

Miskin Yang Tersalib' Di Paroki Mara Satu: Sebuah Sintesa Kristologi Kontekstual.”

Jurnal Orientasi Baru 23, no. 1 (May 21, 2018). Accessed August 4, 2020. https://e-

journal.usd.ac.id/index.php/job/article/view/1136.

Widyatmadja, Yosef Purnama. Diakonia Sebagai Misi Gereja: Praksis Dan Refleksi Diakonia

Transformatif. Yogyakarta: Kanisius, 2009.

—. Yesus Dan Wong Cilik: Praksis Diakonia Transformatif Dan Teologi Rakyat Di

Indonesia. Jakarta: BPK Gunung Mulia, 2010.

Zaluchu, Sonny Eli. "Strategi Penelitian Kualitatif Dan Kuantitatif Di Dalam Penelitian

Agama." Evangelikal: Jurnal Teologi Injili dan Pembinaan Warga Jemaat 4, no. 1

(January 31, 2020): 28. Accessed June 22, 2020.

https://journal.sttsimpson.ac.id/index.php/EJTI/article/view/167. 